\title{
An Identity of One's Own: Feminist Ideology and Identity Crisis of an Academic Woman in a Postmodern Feminist Fiction*
}

ASIST. PROF. SUMEYRA BURAN**

\begin{abstract}
Why academic women struggle to find an identity of their own in "the genderization of science" (Keller, 1984, 78)? Is it because they still "face stereotyping, gendered barriers, exclusion, mobbing, discounting and discrediting in the patriarchal domain of science"? (Buran, 2020). This paper close-reads the interface between feminist ideology and biology that Margaret Drabble develops in her The Millstone (1965), which tells the transition from traditional ideal women to women in crisis in Post-War Britain. This postmodern feminist fiction reconstructs an alternative woman protagonist, Rosamund Stacey, liberated in all facets of life for whom marriage is not the goal but her academic career, as she prefers to remain a single mother without depending on a husband. The aim of this article is to explore how Drabble portrays an academic woman's selfjourney towards a sense of fragmented identity crises of social, familial, professional, and maternal. This is achieved by exploring Rosamund's quest to find her feminist ideology and true identity flying from body constraints and socially assigned female roles.
\end{abstract}

Keywords: Female identity crisis, postmodern feminist fiction, feminist ideology, motherhood, academic woman

\section{KENDİNE AİT BİR KİMLIK: \\ POSTMODERN FEMINIST BİR KURGUDA \\ AKADEMIKK KADININ FEMINİST İDEOLOJISİ VE KİMLIKK KRİZI}

Öz

Neden akademik kadınlar "bilimin toplumsal cinsiyetlendirilmesinde" (Keller, 1984, 78) kendilerine ait bir kimlik bulmakta zorlanyorlar? Bunun nedeni, akademinin ataerkil hegemonyasında kadınların hâlâ "basmakalıplık, cinsiyetlendirilmiş engeller, dişlama, mobbing, küçümseme ve itibarsızlaştırma ile karşı karşıya olmaları“ mı? (Buran, 2020). Bu çalışma, Margaret Drabble'ın savaş sonrası yıllarda geleneksel ideal kadın rolünden kimlik krizi yaşayan kadın rolüne geçişini anlatan The Millstone (1965) romanında işlediği feminist ideoloji ve biyoloji arayüzünü tartışır. Bu postmodern feminist kurgu, bir kocaya bağımlı kalmadan bekâr bir anne olarak kalmayı tercih ettiği için evliliği değil akademik kariyeri amaç edinen hayatın her alanında özgürleşen alternatif yeni modern bir kadın kahramanı (Rosamund Stacey'i) yeniden yapılandırır. Bu makalenin amacı, Drabble'ın akademik kadının sosyal, ailevi profesyonel ve annelik gibi

\footnotetext{
* This article is a revised and extended version of the paper presented at Gender Studies in the Age of Globalization Conference organized by the Faculty of Letters at Spiru Haret University in Bucharest, Romania on 2-3 June 2011.

** Visiting Assistant Professor at University of California Riverside, Department of Gender and Sexuality Studies, (from Istanbul Medeniyet University), sumeyra19@hotmail.com, sburanut@ucr.edu, orcid.org/0000-0003-3273-8125 
parçalanmış kimlik krizlerine doğru kendi yolculuğunu nasıl tasvir ettiğini keşfetmektir. Bu krizler Rosamund'un toplumsal olarak atanmış kadın rollerinden ve beden kısıtlamalarından kaçarak feminist ideolojisini ve gerçek kimliğini bulma arayışını keşfetmesi ile aşılır.

Anahtar sözcükler: Feminist kimlik krizi, postmodern feminist kurgu, feminist ideoloji, annelik, akademik kadın

\section{INTRODUCTION: POSTMODERN FEMINIST FICTION}

eminist literary criticism roots back to the 1960s women's movement, which questions
the traditional representations and images of women in society. Patricia Waugh
regards numerous feminist writers of the twentieth century as postmodern because they attempt to "disrupt the boundaries between art and life, high and popular culture, masculine and feminine, dominant or marginal" (2012, p. 6). Feminists reconsider the historical master narratives and binary discourses in the same way postmodernists question the metanarratives (Kottiswari, 2008, p. 1-2). Feminism and postmodernism focus on "the project of deconstructing both the subject and the 'master narratives' of history" (Hutcheon, 1998, p. 16) and even more on the reconstruction of self since the reproduction of alternative subjectivity becomes more effective than deconstruction. The main focus of feminism and postmodernism is on the construction of otherness. Like postmodernism, feminism also rejects the modernist concept of otherness, which is associated with binary oppositions (self/other) and hierarchies but accepts the postmodern decentering concept of differences that suggests plurality, multiplicity, and heterogeneity (Elbert 1991; Giroux 1991; Hutcheon 1998; Ahmed 1998; Parpart and Marchand 2003; Waugh 2012; Nicholson 2013; Hekman 2013). Margaret Drabble's The Millstone (1965) ${ }^{1}$ displaces the dominant master discourse by reconstructing a new woman self who is liberated from traditional binary structures. Her postmodern feminist writing challenges stereotypes, power, authority, and masculine sexist values that oppress and suppress women.

Post-1945 women writers like Anita Brookner, Sylvia Plath, Ann Tyler, and Margaret Drabble "eschew the narrative experiment of postmodernist fiction [...] espousing a broadly realist aesthetics" and particularly Drabble "shows a greater political awareness of the social (and therefore provisional) and historical determinants of the construction of gender and identity" (Waugh, 2012, p. 127). ${ }^{2}$ Drabble weaves the double standards women faced in the 1950s and 1960s when the ideology of perfect womanhood and motherhood was expected in a nuclear family institution by the patriarchal society. She wrote the novel in an "era where women were explicitly told that happiness could only be achieved through the enactment of a biological imperative, in a society in which all deviance was treated with suspicion" (Smith, 2008, p. 34). Women

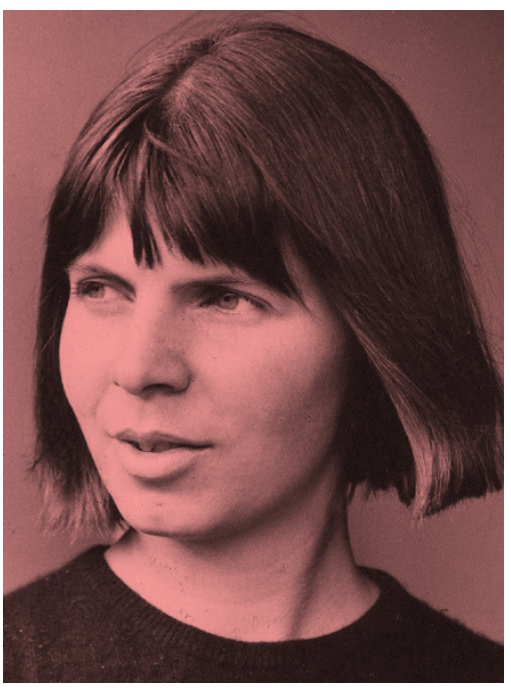

Margaret Drabble

\footnotetext{
${ }^{1}$ It is published as Thank you All Very Much (1969) in America.

2 See also George Soule's Four British Women Novelists: Anita Brookner, Margaret Drabble, Iris Murdoch, Barbara Pym (1998).
} 
were brought into socially assigned roles as perfect wives and mothers because of cultural norms, morals, and values. If these social norms were disregarded, then women were isolated and treated as abnormal. Although Drabble applies the $19^{\text {th }}$-century narrative technique in her novel with her first-person narrative and linear plot, she critiques realism within postmodern innovative narrative techniques employing intertextual dialogues. She portrays postmodern fragmented bodies, selves, and society through her feminist intellectual protagonist, Rosamund Stacey, ${ }^{3}$ who fights for the dominant patriarchal conceptions of femininity with her own subjectivity and multiple fragmented identities.

As Linda Hutcheon defines, postmodernism is "a contradictory phenomenon, one that uses and abuses, installs and then subverts, the very concepts it challenges" $(1998$, p. 3$)$ that Drabble's novel involves the paradoxical essence of the postmodernism and offers another version of reality. We see plural fragmented identities and selves in Rosamund like "infinite plurality of representations" of the postmodern world (Stratton, 1990, p. 320), so Drabble's postmodern fiction depicts the tension between the "presentation and subversion of Realist conventions" (Lee, 1990, p. $70)$.

Although Drabble refuses to be defined as a feminist writer, feminism is the central theme in her novels as she also portrays the struggles of a well-educated academic woman who chooses to have a baby and gets stuck in between her career and her traditional maternal role in the new world. Drabble criticizes the unequal aspects of traditional female roles, and she deconstructs the role of a career woman. Drabble sheds light on the inequalities in the 1950s and 1960s in which social norms and values trapped women. She offers alternative motherhood and childbearing that even mothers can be independent and free without the need of a husband. The novel explores what it means to be a virginal woman who is stuck with her preference to stay alone away from any sexual and romantic relationships in a patriarchal society. Therefore, this paper discusses how Margaret Drabble, in her The Millstone, forms her female bildungsroman around the problems of independent females and their experiences in the modern world by exploring her feminist heroine Rosamund Stacey`s quest to find and define her identity and feminist ideology without dependence on men in such aspects: social, familial, professional and maternal.

\section{FEMINIST IDEOLOGY OF AN ACADEMIC WOMAN}

Male-dominated society constructs the imbalance and inequality between women and men. Katja M. Guenther states that "feminist ideologies are idea systems that recognize an imbalance in power and resources between women and men and that prescribe remedies for this imbalance" (2010, p. 25). As an emancipated, intelligent, and intellectual woman, Rosamund struggles to find out her feminist ideology and female identity within the patriarchal world of the $20^{\text {th }}$ century England. Therefore, this study aims to explore whether a modern academic woman can fulfill her feminist ideology under the pressure of patriarchal ideology. Gordon Bailey and Noga Gayle state that "an ideology is a set of beliefs that seems to serve and shape the interests of a certain group in society; has a legitimating/justifying function; and has the power to control or influence how

\footnotetext{
${ }^{3}$ Like Drabble, Rosamund is an English academic and works on Elizabethan sonnet.
} 
people think about, or act in, their social circumstance" $(2008$, p. 23). As a set of beliefs or idea systems, feminist ideology serves the needs and interests of females in the patriarchal society and aims to influence other women to raise their feminist consciousness and voice within the maledominated society.

In other words, Janet Saltzman Chafetz and Jacqueline Hagan argue that firstly "a central component of feminist ideology, at least during the 1970s, and regardless of nation or specific branch (eg., socialist, liberal, radical), was to encourage women to seek independence, selfgratification and personal fulfillment" and secondly "to discourage them from dependence on men and from devoting all of their energies to the selfless satisfaction of the needs of others (especially those of husbands and, to a lesser extent, of children" (2003, p. 73). They add that "this broad ideological orientation was popularly interpreted especially by middle class, well educated women (the majority of feminists and supporters) to mean independence and fulfillment through rewarding labor force roles; through careers that offer substantial psychic and material reward" (Chafetz and Hagan, 2003, p. 73). Rosamund, as an independent, self-reliant, and emancipated woman, searches for her personal fulfillment and rejects all the domination of patriarchy by not depending on men, but earning her money as a successful academic, and even preferring to remain a single mother instead of living within a marriage which has a patriarchal boundary.

Chafetz and Hagan also claim that "[f]eminist ideology cast an especially acerbic eye on the institution of marriage, which is defined as 'patriarchal'; as benefiting men at the expense of women" (2003, p. 75). Marriage may seem to be a patriarchal institution in which the roles of wives are given and shaped by men, but Rosamund, during her self-quest journey, is not aware of the fact that if equal rights are given both to women and men, then the marriage can break the patriarchal image by fulfilling its sacred value. Virginia K. Beards asserts that Drabble, in this novel, gives an alternative type of feminist woman to the ordinary women by Rosamund, who lives outside of marriage without patriarchal dominance (1973, p. 63). Alternatively, she fights against a patriarchal society by achieving professional independence (Libby, 1975, p. 181). That is, Drabble introduces a new type of free woman who earns her financial and feminist independence on the contrary to the weak type of housewives who are bound up to their husbands, so Drabble`s "heroines are pre-occupied with the difficulties of fulfillment and self-definition in a man`s world, the conflicting claims of self-hood, wife-hood and mother-hood" (Tapaswi, 2004, p. 21). Rosamund struggles to find her self-hood, mother-hood, social-hood, and professional-hood but not her wifehood by rejecting to live within the boundary of a man. As an emancipated woman, Rosamund does not want her independence to be threatened by marriage and a child, but at the end of her self-quest journey, she welcomes a daughter with the help of whom she learns how to love others.

In a traditional male-oriented Bildungsroman, "male writers have used the journey motif to describe a hero's struggle from innocence to experience, childhood to adulthood, immaturity to maturity and identity" which are not achieved through "a sense of isolation but through a sense of connectedness to other people`s physical and emotional needs" (Wojcik-Andrews, 1995, p. 1-2). However, there appeared little attention to the heroine on her journey to gain an identity. Easter Labovitz searching for female bildungsroman claims that the genre has neglected female heroines 
(1986, p. 1). In other words, this genre is considered as male-oriented as if only men can go on journeys in search of their true identity. Like male bildungsroman, female bildungsroman tells the self-journey of the protagonist towards identity and the achievement of the heroine's true identity by the end of her journey. We see bildungsroman's traditional feature of "gradual metamorphosis towards maturity and self-aware" (Kümbet, 2018, p. 89) in the novel with "the voluntarily unwed mother Rosamund [who] gains her growing self-awareness [...] as she moves from innocence to experience" (Spitzer, 1978, p. 227). In this respect, we can consider The Millstone as a female Bildungsroman telling the story of a young scholar and poet heroine's journey both physically (by giving birth) and psychologically toward a sense of identity and her discovery of her true identity by overcoming all her identity crises of social, familial, professional and maternal after moving into sudden motherhood.

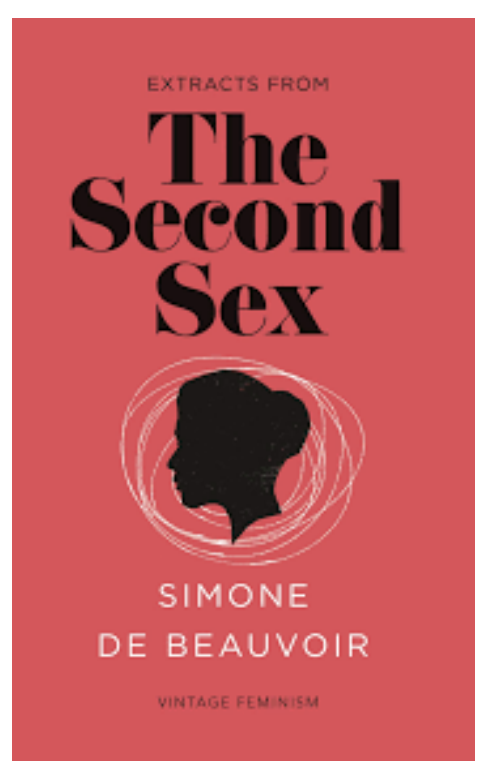

Drabble focuses on the struggles of the educated career woman, Rosamund, in the 1960s who tries to reconcile maternity and career by searching for her identity. Drabble, by this novel, "creates a new pattern, a new blueprint" for women by creating new possibilities and images for them (Drabble, 1973, p. 6). That is, unlike traditional characters, Drabble's female characters have education, professions, and career, and so Rosamund, for instance, struggles to find her identity by rebelling against her parent's ideals about her job, by fighting for a place within the male-dominated academic world, by deciding to keep the child on her own, and by preferring to remain single with her child. Rosamund is a good, devoted mother as well as an intelligent, educated, and free career woman, so she portrays a perfect woman that a traditional man cannot stand this situation. Echoing Simone de Beauvoir's The Second Sex, Drabble outlines the problems of this professional woman and her experience of being a woman in a man's world in which women are regarded as the second sex. Rosamund depicts what it means to be a woman being stuck with a baby in the professional life. Referencing de Beauvoir's famous motto “One is not born, but rather becomes, a woman" (1952, p. 249), Rosamund portrays how she becomes a woman in the patriarchal society which assigns her the status of the Other: "I thought for having born a woman in the first place. I couldn't pretend that I wasn't a woman, could I, however much I might try from day to day avoid the issue?" (Drabble, 1968, p. 16). Drabble depicts the socially constructed concept of gender that women become objects and bodies in a patriarchal world where, as de Beauvoir pointed out, subjectivity is associated with men:

Humanity is male and man defines woman not in herself but as relative to him; she is not regarded as an autonomous being. Michelet writes: "Woman, the relative being..." And Benda is most positive in his Rapport D'Uriel: "The body of man makes sense in itself quite apart from that of woman, whereas the latter seems wanting in significance by itself... Man can think of himself without woman. She cannot think of herself without man." And she is simply what man decrees; thus she is called "the sex," by which it meant that she appears essentially to the male as a sexual being [...] She is defined and 
differentiated either reference to man and not he with reference to her; she is the incidental, the inessential, as opposed to the essential. He is the Subject, he is the Absolute- she is the Other. (1952, p. xvi)

This scene shows that Rosamund rejects the definition of woman in a man's world as "alterity" named by de Beauvoir. Rosamund is not defined in relation to man, but as de Beauvoir claims, "[n]ow, what peculiarly signalizes the situation of woman is that she-a free and autonomous being like all human creatures-nevertheless finds herself living in a world where men compel her to assume the status of the Other" (1952, p. xxviii ). Then, de Beauvoir asks if a woman in this situation could become "an autonomous and transcendent subject" (1952, p. 278), and Drabble answers that question as 'yes' with her independent and transcendent woman protagonist. Rosamund does not care about the status of 'the other' defined by men, she does not need men, and she does not want even sex, but just companionship or friendship. When Rosamund loses her virginity on a one-night stand with a B.B.C. radio announcer, George Matthews, and realizes that she is pregnant, she decides that she also does not need a husband; "I'm one of those Bernard Show women who want children but no husbands?" (Drabble, 1968, p. 119). Thereby, Rosamund fulfills herself without reference to a man.

\section{IDENTITY CRISES OF AN ACADEMIC WOMAN}

Identity, as "one's self-definition is simply answering the question of 'Who am I?'" (Yoon and Muck, 2015, p. 7). One's self-identity can be related to her or his own social environment, norms, and cultures (Speelman, 2001, p. 32-37) because it is social and "constructed through ongoing interactions with others" who have "powerful influences on the individual's development of self-identity" (McGuire, 2008, p. 52). Charles Taylor defines identity crisis as "an acute form of disorientation, which people often express in terms of not knowing who they are, but which can also be seen as a radical uncertainty of where they stand" (1992, p. 27). In other words, it can also be defined as "the experience of questioning what we have taken as a given: 'I have always been like this, but perhaps I could still be otherwise. I could make and live out different choices'" (Josselson, 1998, p. 27). Identity crisis is one's search for an identity in the culture she or he lives in. Identity crisis occurs as a consequence of one's "inner change or social dislocation" (Josselson, 1998, p. 28). Therefore, it is closely related to the outside society, so a person questions and struggles with her or his own self during an identity crisis. Betty Friedan explains the difference between women and men who search for identity like that:

More and more young men in America today suffer an identity crisis for want of any image of man worth pursuing, for want of a purpose that truly realizes their human abilities. (...) But why have theorists nor recognized this same identity crisis in women? In terms of the old conventions and the new feminine mystique women are not expected to grow up to find out who they are, to choose their human identity. Anatomy is woman's destiny, say the theorists of femininity; the identity of woman is determined by her biology (2001, p. 135).

Friedan claims that women woke "from a coma," and they are getting aware of an identity crisis started a hundred years ago. Search for an identity for women will continue until the new 
generation "makes their lives the new image that so many women now so desperately need," that is, they will suffer from identity crisis until they achieve "full human identity" (2001, p. 136). As Friedan states, the depression of women is an identity crisis. Social norms and codes drive women into marriage to fulfill happiness as a wife and mother in terms of traditional feminine roles. These traditional roles have caused depression over women, and particularly those who are in between their career and womanhood. Peter E. Firchow calls Drabble as "miniaturist" for her writing about "female heroines with identity crises" (1976, p. 95). In the novel, Rosamund seeks a new identity by rejecting the female identity of women assigned by society. She gives importance to her independence and career rather than her female identity as a woman: "Our identity is what allows us to define what is important for us and what is not" (Taylor, 1992, p. 30). That is, Rosamund suffers from an identity crisis and so begins to question who she is and what she wants.

Elaine Showalter states that from 1920 onwards, women's literature witness women's search for "self-discovery" and "a search for identity" by focusing on their inside journey (1977, p. 13). Drabble tells the self-discovery journey of Rosamund, who seeks her own identity as a single mother and a career woman. She builds her identity by being alienated and isolated from the social norms through resisting society's well-established institution of marriage. Rosamund has undergone an identity crisis as a consequence of being stuck between her inner desire and the restrictiveness of society's expectations. Her quest for a feminine identity is a result of her isolation and alienation in society. This assigned feminine idealization caused women to be "confused about their inner selves" because of the "distinction between the image promoted by the time's ideology and feminine reality" (Martins, 2011, p. 31) that Drabble exemplifies this with her protagonist Rosamund. The inner confusion of the latter leads her to an isolated position due to her choice. Drabble's Rosamund estranges herself from society instead of conforming to the expected feminine identity.

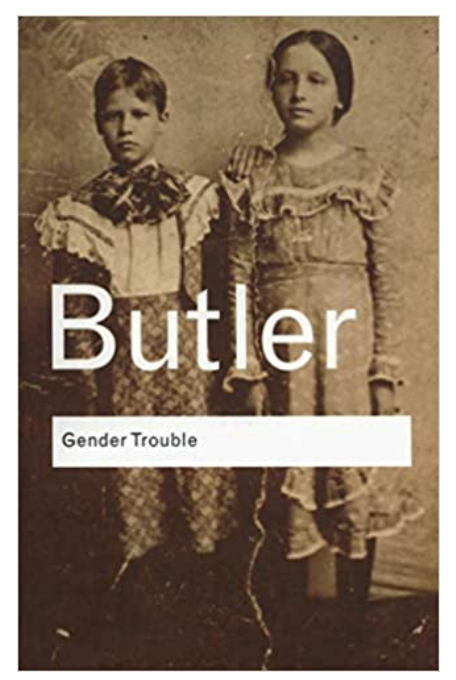

Following Judith Butler's theory of gender performativity, Drabble echoes a good example with her strong feminist character who struggles with women's difficulties in such an era: "Gender is performative," and it "produces a series of effects. We act and walk and speak and talk in ways that consolidate an impression of being a man or being a woman" (Butler, 2015, h. 00:30-0:45). That is, our gender is not constructed biologically but socially through our behaviors and "stylized repetition of acts," which creates "the illusion of an abiding gendered self" (Butler, 1990, p. 140). Thus, Rosamund becomes an abnormal woman with an unfeminine mode of behavior, confronting her biological gender and acting out her femininity in contradictory ways. She raises her voice against the patriarchal system that oppresses her in terms of her romantic and sexual relationship. Her socially constructed self gradually changes her feminine identity. Although her academic identity is advanced, she is a novice in her love life.

Rosamund struggles to complete her own identity away from the constraints of the socially assigned roles because "the core of the problem for woman today is not sexual but a problem of 
identity - a stunning or evasion of growth that is perpetuated by the feminine mystique" (Friedan, 2001, p. 133). As Pamela S. Bromberg claims, Rosamund resists against male dependency "for economic, social and psychological identity" (1986, p. 180). Friedan claims that the "feminine mystique permits, even encourages, women to ignore the question of their identity," which is veiled under the hegemony of their husband's identity (2001, p. 126). This mystique prevents them from questioning who they are as they define themselves as the wife of Mr. Husband or the mother of the Child.

Rosamund's mother "was a great feminist" who raised her with feminist ideologies that prevent her from family, marriage, and traditional womanhood roles (Drabble, 1968, p. 32). Rosamund's initial refusal of sex and fear of sexuality, and then to become dependent on a husband are the subconscious self that she denies. Her life is contradictory that she likes men and longs for love, but she fears sex, she likes independence and "hates to be alone," but she refuses marriage: "I'm not at all sure that I am independent [...] But I would like to be, that's true" (Drabble, 1968, p. 33). What Rosamund needs is a purely romantic love rather than sex, husband, and marriage. Sex has never been a burning desire for her as she gives priority to pure romantic love rather than a husband because freedom and independence are the most crucial things in her life. However, her freedom and empowerment flying from the body constraints end when she finally makes a one-night stand with whom she thinks is gay (or bisexual). She cannot control her body anymore, becoming pregnant, so her female freedom flies. As Sandra Gilbert and Susan Gubar claim, if a woman "denies her own gender, she inevitably confronts an identity crisis" (2000, p. 66), so Rosamund struggles with her own self by choosing a different alternative way. She has an inner-split self that causes her to experience dilemma and identity crisis. Even Drabble herself claims that she feels herself divide:

One can see this in lots of people's writing, that there is a sort of divided self speaking. But I really can honestly say that, unless I am deceiving myself very profoundly, I don't feel that I am, and my characters seem to me not to be, schizoid. [...] Actually, I think that every person is full of contradictory patterns, inevitably. [...] I see my characters as glued together by personality (Hardin, 1973a, p. 282).

Drabble portrays her character almost breaking in parts, but Rosamund, as a strong female character, overcomes all the societal pressures and challenges at the end. Rosamund, during her journey toward a sense of identity, quests for her professional, social, familial, and maternal identity. Rosamund's feminist upbringing by an economist academic father and a feminist mother in an intellectual climate of Fabian society (British intellectual socialist movement) causes her to have a torn feminist identity that she cannot escape from. Her socialist parent's characteristics of emotionless and strict beliefs in equality and independence have led Rosamund to stay away from any kind of dependence, love, and close friendship in her social relations. Rosamund's denial of needing anyone results from her parent's ideologies that she internalizes so thoroughly that she "believed dependence to be a fatal sin" (Drabble, 1968, p. 9). By moving to Africa to teach economics and feminism at appropriate universities, her parents aimed to spread socialist reform. In her parent's ideal world, she is raised to give importance to equality, but she has not been actively involved in the practical world. She believes in sexual freedom, but she fears the physical 
encounter, so we can say that her fear of sex is a kind of heritage from her parent's ideal world. Therefore, she blames her parents for her coldness and isolation from other people: "Sometimes I wonder whether it is not my parents who are to blame, totally to blame, for my inability to see anything in human terms of like and dislike, love, and hate: but only in terms of justice, guilt, and innocence" (Drabble, 1968, p. 93). That is why maybe she avoids the bond for social and emotional relations in her life.

\section{Social Identity Crisis}

Rosamund's parents are well known socialist academics who raise their children by the theory of socialism that is against inequality, separation, and discrimination. When she gets pregnant, Rosamund begins to question her social identity as she cannot emotionally engage with others, and she cannot feel love because of being raised in a political (despite socialist) environment seeing the world through a political and rational lens. Rosamund's journey into a new identity as a result of her pregnancy has taught her to get help from others, so she begins to pay attention to the existence of other women. When she goes to the National Health hospital for her pregnancy, she contacts the working classes for the first time despite her theoretically liberal socialism. Rosamund gets her another shock when she notices other "foreigners; a West Indian, a Pakistani, two Greeks [...] old people respectably shabby" (Drabble, 1968, p. 43), and she wonders where the well-dressed people are. While staying in the hospital for ten days after the birth of her baby, she is amazed at the conversation of ordinary and uneducated women about launderette and handwashing, although washing machines were not a luxury at that time. Rosamund cannot understand the struggles and problems of these women, but she "discovers community by giving birth" (Mye, 1991, p. 35). Thus, we can say that Rosamund not only fights for her place in a patriarchal society as an academic woman, for her decision of remaining a single mother and for her preference not to share her baby with one-night stand biological father but also fights for the feminist ideologies inherited by her parent.

\section{Familial Identity Crisis}

Rosamund 's lack of parental love and care causes her to feel familial identity crises, and she remembers this emptiness whenever she dives into an emotional relation. For example, just before Rosamund and George have sex and when he starts to kiss her fingers one by one, she remembers "what was at the back of my [her] mind" and tells him, "my mother, you know, was a great feminist. She brought me up to be equal. She made there be no questions, no difference. I was equal. I am equal" (Drabble, 1968, p. 33). Because she cannot be aware of her femaleness, although she is a strong and free woman, she always feels anxious about the first encounter, which causes her fear of sex. She relates her fear of sex to her cowardice because she hesitates to dive into an emotional relation:

My career has always been marked by a strange mixture of confidence and cowardice: almost, one might say, made by it. Take, for instance, the first time I tried spending a night with a man in a hotel. I was nineteen at the time, an age appropriate for such adventures, and needless to say I was not married. I am still not married, a fact of some 
significance, but more of later. The name of the boy, if I remember rightly, was Hamish. I do remember rightly. I really must try not to be deprecating. Confidence, not cowardice, is the part of myself which I admire, after all (Drabble, 1968, p. 7).

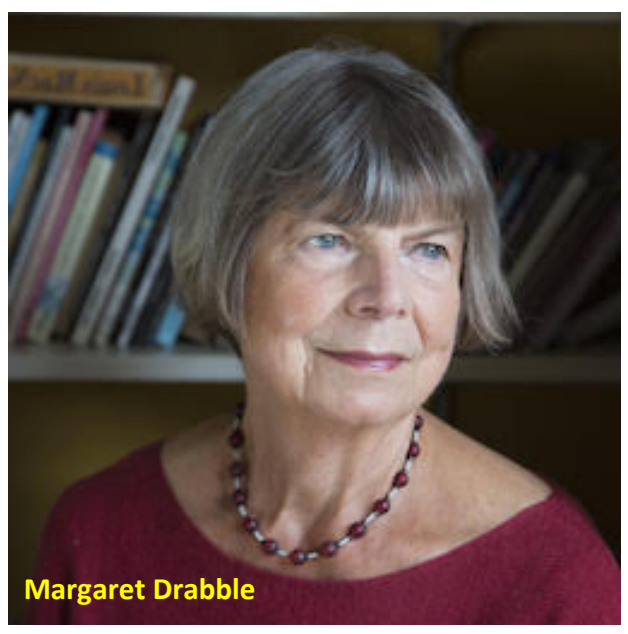

Rosamund admires her confidence, but nevertheless, she feels coward in terms of sexual encounter though her age is appropriate for it in the 1960s London. She and her boyfriend Hamish, in advance, plan to spend a night at a hotel. They pretend to be married in order to stay together in the hotel, but Rosamund signs the register with her maiden name, "I had accidentally told the truth, I had meant to lie, and she [receptionist] had expected me to lie, but for some deeply rooted Freudian reason I had forgotten to do so" (Drabble, 1968, p. 8). Hamish corrects her mistake, making a few jokes about their marriage. Rosamund`s reference to Freud reminds us that she subconsciously does not want to sleep with Hamish, so she accidentally blunders.

Tuzyline Jita Allan claims that Drabble's women protagonists live in the definition of the patriarchal world, and Rosamund tries to conceal her femininity until she meets George (1995, p. 63). Although Rosamund is not interested in sex, she tries to hide her virginity, so she makes her two boyfriends Joe and Roger think that she is having an affair with the other. Rosamund does not find Joe and Roger attractive enough although they are interested in her, that is, she dates with two men who try to get her in bed, but she prefers to remain a virgin: "I liked men, and was forever in and out of love for years, but the thought of sex frightened the life out of me and the more I didn't do it and the more I read and heard about how I ought to do it, the more frightened I became" (Drabble, 1968, p. 21). Rosamund's fear of intimacy shows her fear of losing independence as a consequence of the social construction of her gender identity. Her in-between situation continues when she learns that she is pregnant after a one-night stand with George.

On the one hand, she sees this situation not as a punishment for one-night sleep with George: "But rather for all those other evenings of abstinence with Hamish and his successors. I was guilty of a crime, all right, but it was a brand new, twentieth century crime, not the good old traditional one of lust and greed," and she adds that "my crime was my suspicion, my fear, my apprehensive terror of the very idea of sex" (Drabble, 1968, p. 21). Rosamund's millstone gives reference to Hawthorne's Scarlet Letter as one of the intertexts in the novel. Rosamund sees herself as a modern Hester Prynne, the young protagonist in The Scarlet Letter, who was condemned by her Puritan neighbors for her adulterous affair. However, Rosamund has not committed adultery, but has a baby out of wedlock, and she says:

I walked around with a scarlet letter embroidered upon my bosom, visible enough in the end, but the A stood for Abstinence, not for Adultery. In the end I even came to believe that I got in thus, my punishment, because I had dallied and hesitated and trembled for so long. Had I rushed in regardless, at eighteen, full of generous passion, as other girls 
do, I would have got away with it too. But being at heart a Victorian, I paid the Victorian penalty. (Drabble, 1968, p. 21-22)

This scene depicts that the novel questions why Rosamund pays the price and for what she is punished, being a woman and remaining virgin so long until the first encounter. Using intertexts as a reference to the past, Drabble portrays the difference between traditional and contemporary women. Unlike the domestic ideology of women as angels in the house, Drabble uses motherhood as a symbol of femininity that Rosamund pays for being female by her unpredicted pregnancy because, as a modern woman, she must have had her sexual encounter when she was 18 like the other girls.

Another obvious intertext is Samuel Daniel's a sixteenth-century poem The Complaint of Rosamund, which Rosamund studies in her Ph.D. dissertation. The poem is a kind of ironic mirror to real Rosamund's dilemmas. In the poem, Fair Rosamund is killed by the jealous queen because of being the mistress of Henry II. Peter Firchow asserts that Drabble`s novel is "a reversal of the traditional plight of the violated maiden" (1976, p. 97). A jealous queen does not poison Rosamund, but she finds an illegitimate baby as a symbol of status because her baby does not bring her shame but great joy and salvation. If Rosamund had lived in the sixteenth century in place of Daniel`s Rosamund or Hawthorne`s Hester Prynne, she would have committed a social crime with her illegitimate baby, but now she commits a twentieth-century crime by remaining virgin so long as a result of her abstinence from sex.

In the same way, if Drabble had lived in the Victorian Era, she would probably portray a weak and angel woman who would call George after getting pregnant at least for financial and emotional support without regarding her female pride and ideology. Unlike traditional women, she is not regarded as a prostitute because of her pregnancy, but the price of her independence costs high, or she has a feeling of being punished for her being both a woman and remaining virgin long. So, now she has to choose either her baby or her career; alternatively, she will continue both. Because of such difficulties, most academic women would prefer to stay aloof from marriage, serious relationship, or pregnancy; otherwise, they need to carry extra burden or millstone in their academic life.

\section{Professional Identity Crisis}

The rate of academic women was very low in the 1960s British universities. ${ }^{4}$ In those years, thanks to feminist movements, sex was "open to public discussion," and this freedom of speech "increased toleration of sexual behavior formerly frowned upon; the biggest change was that young people lived openly together and produced children outside marriage" (Myer, 1991, p. 14).

\footnotetext{
${ }^{4}$ Kathleen Ollerenshaw argued in 1961 that "too few girls go on to higher education. We need more well-educated women to help in building happy and cultured homes, to work in the professions, particularly teaching, and to make the best contribution generally to the community" (1961, p. 134). For example, in British universities, only 12.2 percent of all academic staff was women, only 11.4 percent held senior positions and only 23.7 percent of women students were on degree courses in 1951 but in 1972, 10.9 percent was academic staff, 12.0 percent held senior positions and 32.4 percent of students were on degree courses (Heward, 1996, p. 12). And, Sommerkorn claimed that there were fewer than 30 women professors in the entire nation in 1962-3 (qtd. by Blackstone, 1974, p. 43).
} 
However, freedom brings confusion or conflicts for modern women whose responsibilities and burdens continue in the house besides their careers. In 1966, historian Constance E. Arreger wrote that women "have a double contribution to make. They have their contribution through their professional work, and they have their contribution as wives and mothers" (1996, p. xvi ). Therefore, Rosamund's situation between her academic life and her pregnancy splits her into two; between her personal (femininity, motherhood) and intellectual self, and this split causes her crises in her professional identity.

The reason for this split is that although feminists achieved many social advances, society still holds different gender expectations for women and men, particularly in academic and familial fields. Academic women are often forced to choose their intellectual interests or their conventional gender role. While men can easily separate their private lives from a professional one, women are expected to run two of them together as a housewife and babysitter, and as an academic. Although women split themselves into many fields, they are still discouraged, suppressed, and repressed by the dominant patriarchy, so they need to try hard in order to fulfill themselves in the public domain, which is still regarded as a male territory because they cannot escape from the responsibility of domestic domain. Hence, most modern women are expected to combine family and career successfully together as they choose two of them.

In the novel, although Rosamund's sister Beatrice is also "educated to be independent and to consider herself the equal of anyone alive" (Drabble, 1968, p. 85), she leaves her academic career in economics for the sake of her marriage. Following the views of de Beauvoir`s attack on women's regarded identity as the second sex and Friedan's attack on the myth of happy housewife, Drabble employs her idea through Rosamund that any women, particularly an educated woman cannot be happy being merely a wife and mother. When Rosamund visits one of her old Cambridge friends, she condemns her friend: "my friend had been at Cambridge with me and was now, to her great annoyance, nothing but a wife and mother, and really I felt I was the better off of the two" (Drabble, 1968, p. 165). In short, women often sacrifice their academic careers for the sake of motherhood and wifehood (seeing it as a millstone) or the very opposite; they sacrifice themselves for their academic careers by remaining single (seeing a child a millstone and a husband a hindrance to their independence).

Before her pregnancy, Rosamund has a divided self between her professional identity and social identity. As Ronald David Laing says, people who have split-selves "experience themselves as primarily split into a mind and a body. Usually they feel most closely identified with the mind" (1978, p. 65). Rosamund is "threatened by internal division and achieves integration through fate" by discovering the possibility of a unified self (Libby, 1975, p. 183). Because of her pregnancy, Rosamund is forced to go to the outer world where she has isolated herself from like a creative artist, and she accepts her own biological existence. Maurice Beebe claims that the fictional portrait of the artist has a divided self, and the major focus of the artist novel is the quest for self, which is always in conflict with society, so the artist as hero/heroine becomes the artist as an exile. The creative artist has a divided self as a human being and an artist. The human being self has conventional appetites and desires, but the artist self looks down on the human being by isolating 
himself from society. The artist self sees himself as a superior being, so desires freedom by escaping from the demand of life while his man self seeks personal fulfillment in experience, so the artist should stand between the Ivory Towers and the Sacred Founts (Beebe, 1964, p. 6-18). Rosamund cannot make a balance between the external world and her personality, between her career and society, and between the inner and the outer world, that is, she values her ivory tower above everything. Hence, we see her sense of split between her head and her heart in this novel. When Rosamund gets pregnant, for the first time, she recognizes herself as a woman that she has avoided before; then, she becomes aware of the others. After her baby, she begins to live in harmony within herself and with her environment, and her divided self, which is stuck in between the ivory tower and sacred fount, ends with the harmony of love and success, or in other words, with the harmony of her professional identity and social identity.

Rosamund is strongly opposed to any kind of dependence on men, such as emotional, financial, physical, or intellectual, so she stays away from sex until her one-night stand with George. Although she knows it is just a one-night stand, she still chooses him as her first sexual partner because: "there seemed to be some deadlock between us that could never be broken...but I knew that a connection so tenuous could not last, could not remain frozen and entranced forever, but must melt if so left, from the mere mortal warmth of continuing life" (Drabble, 1968, p. 187). One of the reasons why Rosamund chooses George as her first sexual partner is that as a bisexual, he is less intimidating one for her and she says: "Knowing that he was queer, I was not frightened of him at all" before having sex with him, and she adds "because I thought he would expect no more from me" (Drabble, 1968, p. 33). The other reason is that she does not want to hurt his feelings as she likes him: "before I knew where I was I found myself thinking that I couldn't stop him if really wanted to because I liked him so much, and if I stopped him he would believe that I didn 't: also that if ever, now: also that it would be good for me. So I shut my eyes, very tight, and waited" (Drabble, 1968, p. 34). She likes him enough to make him her first sexual partner but not enough to make him her husband. Their lack of communication and intimacy causes them to have formal and automatic lovemaking, and she says, "he seemed to know quite well what he was doing: but then, of course, so did I seem to know, and I didn't. However, I managed to smile bravely, in order not to give offense, despite considerable pain, and I hoped that the true state of affairs would not become obvious" (Drabble, 1968, p. 34). She tries to hide her sexual inexperience and cowardice behind her fake braveness, and George, in the same way, is formal throughout the lovemaking as if to hide his queerness. Then, when George attempts to leave, she does not prevent him because she "did not quite know whether I [she] ought to suggest that he might stay" (Drabble, 1998, p. 36). That shows us that her cowardice and familial crisis still continue because she cannot find enough courage in herself to start a serious relationship with a man as she is not sure about his sexual choice:

I did not have the courage to ask him where he lived, or to ask him what his phone number was, for it would have seemed an intrusion, an assumption that I had a right to know, that a future existed where it would be of use to know...I cannot get out and say, Where do you live, give me your number, ring me, can I ring you? In case I am not wanted. In case I am tedious. So let him go, without a word about any other meeting, 
though he was the one thing I wanted to keep: I wanted him in my bed all night, asleep on my pillow, and I might have had him, but I said nothing. And he said nothing ... He could have said, when can I see you again? But he didn't. It may be that I manifested enough strangeness and indifference to prevent him. It may be that he did not wish to, which, being the most unpleasant conclusion, was the one that I most readily believed. Or it may have been that, like me, he did not wish to make assumptions. (Drabble, 1968, p. 36-37)

Rosamund may call and find him at the pub, but "pride restrained me. If he does not want to see me, I thought, I do not want to see him" (Drabble, 1968, p. 38). She goes between her heart and mind and finally prefers her mind. It takes some time for her to realize that she is pregnant, but she continues to disregard her emotional identity, "it gave me much satisfaction, this fact. Much selfsatisfaction [...] I discovered another source of satisfaction: now, at least, I would be compelled to see George. I had an excuse, now, for seeing him" (Drabble, 1968, p. 39). However, later she changes her mind, "I decided to get on with it by myself as best I could" (Drabble, 1968, p. 39). At first, she attempts to tell the baby to George so that he can enjoy the baby like her, but later she decides to keep the secret from him because he may want her to have an abortion, or he may force her to marry him just for the baby. We can say that she likes him because she has waited for his call throughout the novel. However, her pride prevents her from telling the paternity of George because he has caused her to think that she is unwanted. That is, Rosamund wants George to turn back to her just for his love but not for the baby.

\section{Maternal Identity Crisis}

Drabble epitomizes feminist ideology and expectations of academic women who can combine career and family successfully by exposing the idea that women's independence should not be threatened by motherhood or womanhood. Even today, most successful women prefer to remain single, worrying about whether they can successfully balance their motherhood and career, whether they can be accepted professionally by men or how motherhood and womanhood will affect their professional performance. Rosamund feels these anxieties after her pregnancy, and the reason for her maternal identity crisis results from this threat; she says, "I feel threatened. I felt my independence threatened: I did not see how I was going to get by on my own"

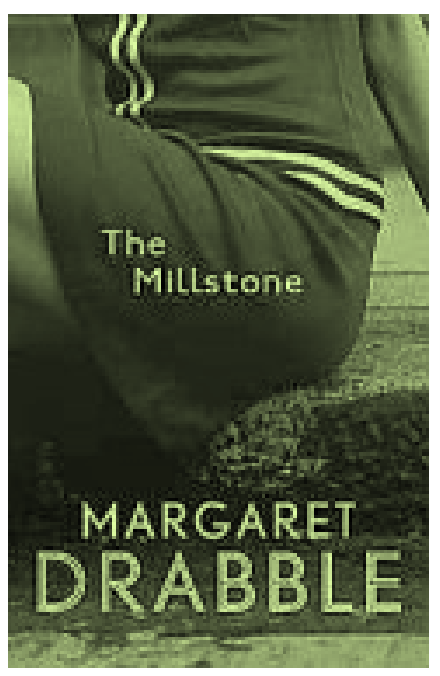
(Drabble, 1968, p. 44-45). The reason for the maternal identity crisis of Rosamund results from her motherhood because, like most modern women, she goes between her desires and fears of this role. However, at the same time, she is "in some perverse and painful way quite proud of [her] evident fertility" (Drabble, 1968, p. 48). That shows how she is confused about her motherhood that "I suddenly felt quite overcome with weakness and misery. At that point, I could not envisage any kind of future at all, and the complete lack of any sense of control or direction scared and alarmed me" (Drabble, 1968, p. 49). She undergoes a maternal identity crisis and is split between 
whether her child will slow her career and life as a kind of millstone, or she can be a good and devoted mother beside her career. Thus, she fears whether her baby will affect her independence.

Then, she tries a comic attempt at an abortion, preparing a bottle of gin to drink in a hot bath, but the gin is consumed by her friends who drop by. She realizes that she will get more upset by having an abortion than having the baby, and she drunkenly confesses that she wants the baby, "My sister had babies, nice babies, and seemed to like them. My friends had babies. There was no reason why I shouldn't have one either, it would serve me right [...] I might as well pay, mightn 't I, if other people had to pay?" (Drabble, 1968, p. 19). Hence, she continues to write and becomes a successful scholar because she is ready to pay that price even if it may cost her career. Growing in a well-educated family, Rosamund feels brave to pay the price. Her feminist mother passed her the feminist ideology of freedom, independence, and self-reliance that Rosamund cannot prison herself into marriage and dependence on a husband, so she decides to keep the baby only to herself. Rosamund's sudden pregnancy makes her feel she is "trapped in a human limit for the first time in [her] life, and [she] was going to have to learn how to live inside it" (Drabble, 1968, p. 65), and she chooses the independence again to raise the baby on her own. By this way, her baby does not become a kind of burden to her because she knows that both her own social status and her promising career will help her to raise her child in a right way:

I had been offered a good job for the following autumn at one of the most attractive new universities, my thesis was at the publisher's and on the strength of it my name was in considerable esteem amongst those in a position to esteem it... It was gratifying, too, that my name would in the near future be Dr. Rosamund Stacey, a form of address which would go a long way towards obviating the anomaly of Octavia`s existence" (Drabble, 1968, p. 172-3).

The power of Rosamund comes from her economic independence and her confident feelings of her academic abilities, "scholarship is a skill and I am good at it, and even if one rated it no higher than it is still worth doing" (Drabble, 1968, p. 105). She portrays a good role model for an academic woman; she is successful, determined, and has a rigorous discipline. In this respect, Drabble asserts that women do not need to be forced to choose between their femininity and professionalism. At first, Rosamund has some worries regarding if she can manage her career with a baby who threatens her independence or not, but later she releases her maternal anxieties by separating her career from her feelings of motherhood and femininity. Her unexpected pregnancy offers her another life to live independently with her baby. The pregnancy of an academic woman may seem to be a kind of social crime, but it helps Rosamund to improve her concentration on her study, "my Elizabethan poets did not pale in comparison with the thought of buying nappies" (Drabble, 1968, p. 76). She focuses her energy more comfortably on her dissertation that she completes it ahead of schedule, "I simply did not believe that the handicap of one small illegitimate baby would make a scrap of difference to my career [...] I would win, though the evident superiority of my mind" (Drabble, 1968, p. 125). In the end, we see that Rosamund fulfills her goals by publishing her dissertation and finding a postdoc position at one of the prestigious universities. Drabble depicts that a woman can both have a career and a baby that her intellectual development improves with the power of love the baby brings to the mother. Drabble does not 
unite all these four identities of Rosamund at the end, being a successful career woman, a loving mother, a wife, and a happy social woman. Her female identity is fulfilled as a single mother and a successful academic.

\section{MARRIAGE AND MOTHERHOOD: WHO IS AFRAID OF BEING A SINGLE MOTHER?}

I argue that there is a mutual relation between reproduction and intellectual production. Showalter asserts that Drabble "finds a female resolution to the feminine conflict between biological and artistic creativity" and motherhood "is a way of knowing, a process of education that not only helps Rosamund work 'with great concentration and clarity' on her thesis, but also makes real to her the abstractions of the human
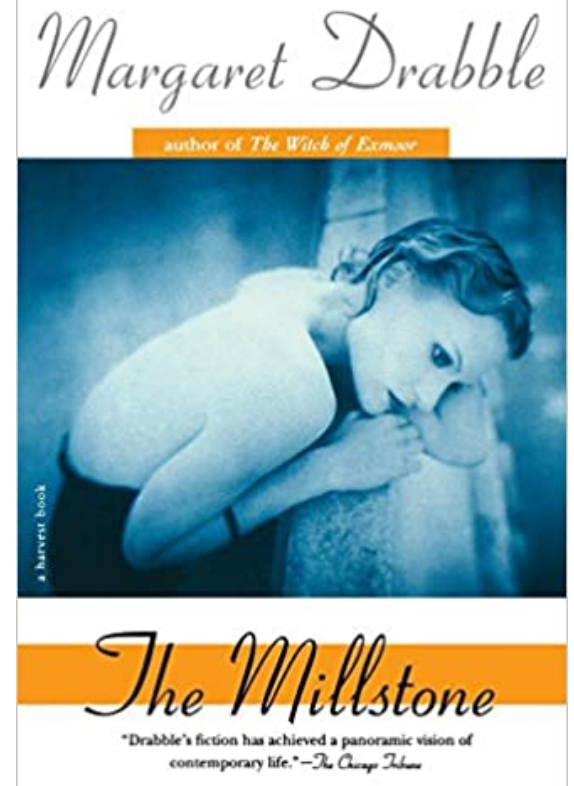
condition" (1977, p. 306). Susan Suleiman stresses on maternal creativity that "in The Millstone, the heroine writes better after her child is born" (1985, p. 377). That shows Drabble herself has a positive view about motherhood, "once you've had your first child, it's no use being a high flyer anymore. If you want to do anything, you've got to turn into a practical person whether you like it or not. You learn to conserve your energies, and to use them properly" (Poland, 1975, p. 257-58). So, she weaves the theme of mother-daughter relationship and motherhood by eliminating the father figure. ${ }^{5}$ Drabble proves with her heroine that nothing can be an obstacle to women's intellectual capacity and development, even the babies with whose love they can find energy and power.

Drabble portrays motherhood "not as an institution under male control, as it is so often defined, but as the relationship of a woman to her powers of reproduction and to her children" (Rayson, 1978, p. 43). By having a daughter, Rosamund experiences the greatest pleasure in her life, the real love, because she is not successful in romantic love: "Lucky in work, unlucky in love" (Drabble, 1968, p. 11). Marriage is portrayed as a loss of independence while the significance of maternity is depicted as a kind of salvation. As Ann Rayson claims, Drabble "ushers in a new era for the woman writer in which the relationship between a mother and her children is catalytic rather than destructive" (1978, p. 43). That is, motherhood is the central experience of Rosamund, who finds salvation with her daughter.

Rosamund regains another identity through her pregnancy, and she gets sensual pleasure by giving birth, so Rosamund, as a modern woman, portrays a strong woman type who handles both motherhood and career successfully: "I found I was working extremely well at this time and with great concentration and clarity. I thought continually and with relief that I was as sure about the Elizabethan poets and as I was sure that I liked baked potatoes" (Drabble, 1968, p. 76). Her motherhood and baby do not interfere with her career, but instead, it brings about her ability to

\footnotetext{
${ }^{5}$ This might result from Drabble's her own lack of father figure in her childhood because her father was away in the War time.
} 
improve more in her work. After she delivers her baby, she claims that "I was not (much used to) feeling happiness: [real] satisfaction, perhaps, or triumph, and at times excitement and exhilaration. But happiness was something I had not gone in for a long time, and it was very nice, too nice" (Drabble, 1968, p. 115). Rosamund tries to explain her feelings when she first holds the baby: "I felt it is pointless to try to describe. Love, I suppose one might call it, and the first of my life" (Drabble, 1968, p. 114). On one side, Drabble depicts the depth of love between mother and her child, and Rosamund sees that her daughter loves her too; "Gradually I began to realize that she liked me, that she had no option to liking me, and that unless I took great pains to alienate her she would go on liking me, for a couple of years at least. It was very pleasant to receive such uncritical love, because it left me free to bestow love" (Drabble, 1968, p. 128)

Drabble portrays an independent woman who only cares about her career and protects her daughter against social stereotypes and norms. In the beginning, Rosamund calls herself an "unhappy woman" (Drabble, 1968, p. 93), but after Octavia, she becomes aware of love and happiness, "I knew something now of the quality of life, and anything in the way of happiness that I should hereafter receive would be based on fact and not on hope." (Drabble, 1968, p. 158). Then, as Rose says, "for becoming a mother does offer Rosamund an opportunity to break down the walls of her isolation and connect, lovingly and vulnerably, with another" (1980, p. 18). Rosamund's daughter awakens her from her academic isolation:

At times I had a vague and complicated sense that this pregnancy had been sent to me in order to reveal to me a scheme of things totally different from the scheme which I inhabited, totally removed from academic enthusiasm, social consciousness, etiolated undefined emotional connections, and the exercise of free will. It was as though for too long I had been living in one way, on one plane, and the way I had ignored had been forced thus abruptly and violently to assert itself. Really, it was a question of free will; up to this point in my life I had always had the illusion at least of choice, and now for the first time I seemed to become aware of the operation of forces not totally explicable and not therefore necessarily blinder, smaller, less kind or more ignorant than myself. (Drabble, 1968, p. 67)

This passage shows that Drabble portrays different types of identity crisis that Rosamund experiences as a woman, an academic, a mother, and an anti-wife. Women undergo identity crises because "the price of wifehood" is an abandonment of self (Heilbrun, 1993, p. 175). So, Rosamund searches for her place in society while suffering from a crisis of identity, whether to stay in academia or marital life.

Rosamund also struggles with her motherhood self. Her preference to stay a single mother refusing the restrictive feminine roles and the established norms of the family institution lead her isolation from society. She fights with her socially constructed self. When she understands that she is pregnant, the doctor shows us the socially constructed norms that she should be married: "He told me to sit down and asked me what she could do for me, and I said I thought I was pregnant, and he said how long had I been married, and I said that I was not married" (Drabble, 1968, p. 44). His reaction is "more in sorrow than in anger" (Drabble, 1968, p. 44) as if she, as a single mother, does not admit her status in society. Considering that Rosamund feels shame by her choice, the 
doctor suggests the Unmarried Mothers in the town where she can find helpful people about adoption. Even the midwife does not ask her feelings and the baby's name, "she presumably assumed the child would not be mine for a long, but did not care" (Drabble, 1968, p. 118). The reaction of the doctor and the midwife show that being a single mother without marriage is considered a shame for a woman who would probably give the child for adoption, but Rosamund does not consider her pregnancy as something socially wrong but a gift. Rosamund's choice to continue her life on her own with her baby portrays an image of a new woman against established social norms and feminine norms that drive her away from the traditional ideal woman. By choosing her own path, Rosamund desires an unusual family as a single mother with her career. Taking the responsibility of a baby drives her isolated from society by refusing sexual activity and feminine expectations because she prefers to have a solo family without marriage and a husband.

After the baby is born, she lives happily in her alternative way without remorse. She finds her own self and fulfills happiness with the love of the baby. Rosamund had a fear of sex, but she got pregnant, she had a fear of motherhood but overcomes with pure love, she denies the marital institution, but she begins to worry about George. Rosamund's fragmented identities offer her the meaning of life thanks to the feeling of eternal love to her baby that she has been longing. She does not feel a loss of independence with her baby. The last sentence of the novel explains her state of self "It's my nature. There's nothing I can do about my nature, is there?" (Drabble, 1968, p. 199) implying that there is nothing for her to get rid of her split identities, so she needs to get accustomed to living with her diverse identities. The identities make her who she is and all a part of herself and her nature. She does not feel isolated anymore because of the fear of the people's reactions after she delivers her daughter and finds the true pure love in herself. Cultural expectations continue to trigger an identity crisis for Rosemund, who creates an alternative way to live with her daughter's love and rejects social norms. She fights for her identity alone, following her desires regardless of the people's expectations and reactions. Her baby becomes not a millstone to her anymore as the marriage and a husband would be. That is, her experience of identities builds up her character.

Gail Cunningham argues that Rosamund gets rid of her isolation by conceiving a child and needing the help of strangers while bearing and raising her baby because she has a deep feeling for her daughter (Drabble, 1968, p. 64). By her career, Rosamund develops her theoretical and intellectual sides, but her emotional side is neglected as she has arranged her life to avoid a close relationship with others, so by giving birth, she learns the importance of love and the importance of giving as well as taking, and learns that she is related to all other people around her. To the end of her self-journey, Rosamund begins to think that she can be a good mother as well as a good scholar, and a baby cannot be a heavy burden (millstone) for her life. As Nancy S. Hardin claims, after Octavia Rosamund lost her control over much of her life and career by saying "as a result of her millstone, she regains the lost dimension of depth in her own life" (1973b, p. 25). Rosamund learns how to love after the baby is born and learns more about herself and understands her identity. Her pregnancy reminds her of her feminine and biological identity. She uses her academic research by which she can stay aloof from society because it becomes a formative 
principle in her identity. She prefers to study in the field of literature through which she can differentiate herself from her family's intellectual values and interest in economics and history. Rosamund realizes that she has devoted herself to her career so much that she neglected her femaleness but not her independence. Hence, her pregnancy forces her to go outside her normal academic rationality to emotional fulfillment that mothering brings.

Some critics blame Rosamund for being selfish for concealing her child from George. For example, Carol Seiler- Franklin regards Rosamund as "selfish" (1979, p. 115), and Ellen Cronan Rose questions Rosamund as "[s]he may well be sparing herself, but has she any right to 'spare' George the knowledge of his paternity? Isn 't he entitled to the sense of obligation, as well as to the sense of pleasure, which parenthood affords Rosamund and which she selfishly claims as her sole property?" (1980, p. 19). Rosamund had her first encounter with George because he was the first less frightening person, and she liked him and wanted to get rid of her virginity, but she did not imagine she would be pregnant in her first attempt. Rosamund's sister reacts Rosamund's decision as well; "It would be bad enough for you, but it would be far, far worse for the child. Through no fault of its own it would have to have the slur of illegitimacy all its life, and I can't tell you how odiously cruel and vicious children can be" and she warns Rosamund that "a baby isn 't just something you can have just because you feel you ought" (Drabble, 1968, p. 87). As Rose claims, Rosamund just thinks of her pride and independence selfishly by not letting George know his paternity.

However, on the other side, we cannot expect a woman to accept a one-night stand man as a husband who does not call her after the sexual encounter or marry a man just for the baby. The novel shows us another option as what Rosamund does; she reconciles her intellectual and feminine identities by succeeding both as a liberated loving mother and a successful scholar by living without depending on a man in every field of life. However, this time she sacrifices her female sexuality (sexual desire) for her career and love (for her daughter). And she also selfishly sacrifices her daughter for the sake of her feminist ideology and independence by depriving her of the love of her father's. Rosamund does not believe that her baby will suffer from a lack of a father because she believes that her love will be enough for Olivia, for whom Rosamund can act double roles of parents for the rest of her life. Rosamund cannot realize that she would prevent the fatherdaughter relationship and the parental love of which Rosamund lacked from her own parents. That is, "women struggle to re/constitute their female or feminist selves" like Rosamund who is split between her feminist ideology inherited from her parents and her female self constructed by the patriarchal society (Özer-Taniyan, 2012, p. 256) eventhough she achieves her spiritual salvation recovering her divided self thanks to her motherhood at the end. Thereby, we cannot talk about a close ending but an uncertain open ending that, as readers, we cannot be sure whether Rosamund will continue her feminist triumph over men as a consequence of her radical feminist upbringing.

\section{CONCLUSION}

Drabble is famous for her open endings, and she ends The Millstones with George`s finally seeing his daughter. The final scene shows that Rosamund tries to get rid of her loneliness and 
recover her emotional emptiness and longings for love and family when she runs into George and invites him home for Christmas Eve on her way to the hospital for Octavia's prescription. She regards this event as the final fate of herself: "the circumstances have an indelible beauty, like the beauty of fate itself" (Drabble, 1968, p. 172). That is, Drabble reunites the virgin woman and her baby with the father on Christmas Eve as a kind of happy heterosexual ending. Rosamund thought that the meaning behind the accident (her pregnancy) was her fate, which was associated with her free will because she was free to choose her first sexual partner, and now she feels herself free to choose him as her husband. Then, when the second accident happens, Rosamund and George meet again, she realizes that their fate reunites them again like the accident of the baby; "I neither envied nor pitied his indifference, for he was myself, the self that but for accident, but for fate, but for chance, but for womanhood, I would still have been" (Drabble, 1968, p. 191). However, Rosamund prefers not to tell that he is the father of her baby for many reasons: first, she claims that George is bisexual; second, maybe she does not want to share the love of her baby; third, he has not called her since their first sexual encounter; fourth she hides behind her pride; fifth she does not want to be seen in need of a man as she is a strong woman; sixth she feels he cannot be a good father and husband, or she is not ready for another responsibility. That is, she finds excuses as she is angry at him one one side but she feels upset when George says that he may go abroad, so she confesses to herself that she still loves him:

I felt myself on the verge of tears and noise, and I held hard onto the arms of my chair to prevent myself from throwing on my knees in front of him, to beseech from him his affection, his tolerance, his pity, anything that would keep him there with me, and save me from being so much alone with my income tax forms, from lacking him so much. Words kept forming inside my head, into phrases like I love you, George, don't leave me, George. I wondered what would happen if I let one of them out into the air. I wondered how much damage it would do (Drabble, 1968, p. 189).

We can say that the novel leaves the door open for reunion. When George asks her, "you can come with me, if you want" to the abroad, she asks if she can bring her daughter too (like a family) by praising her; "My baby is a nice baby" and "She`s very pretty" as if trying to warm him to fatherhood (Drabble, 1968, p. 189). Then, George compliments Rosamund through the baby; "I don't see why you shouldn't bring her [. . .] How could she not be pretty? [. . .] with such a mother? And I like her name, too" (Drabble, 1968, p. 189). George admires her independence in deciding to have a child on her own. To see how the wind blows, George says that Rosamund has "a nice job, and a nice baby. What more could anyone want? [...] You never seemed to want a husband" as if he might be a candidate husband and father to his own child (Drabble, 1968, p. 190). Rosamund replies that "some people might want a nice husband too" as if accepting his proposal but George tells her that she "can't have everything" as if we are reminded of his bisexual and queer side that Rosamund can only have a half husband (Drabble, 1968, p. 190). Rosamund says she sometimes thinks it would be easier to have a husband "to fill in my income tax forms" though she earns her own money, and George says, "I feel it would be nice to have someone to iron my shirts" though he is accustomed to doing his own duties (Drabble, 1968, p. 190). By remaining single, both have established their own independence. However, George admits that they need to 
find another reason for their need for each other and they both know that this reason is "love" and "we [they] smiled at each other" then Rosamund lets him see their daughter, and she welcomes him to her private life as the first step to a reunion.

Consequently, Drabble by this novel helps to raise the female consciousness of academic mothers who feel identity crises searching their true selves in a patriarchal world by splitting themselves into many identities. After her psychological journey toward a sense of identity, Rosamund gets rid of all her identity crises by fulfilling herself. By questioning her social identity, Rosamund shifts into a new identity that teaches her to accept help from the others, and she begins to be aware of the existence of the others. Hence, she transfers from a sense of isolation to a sense of connectedness to other people. Next, Rosamund overcomes her familial identity crisis stemming from the lack of her parental love and cares by diving into a passionate, emotional relationship with her daughter and George. When she begins to see that a child cannot be a millstone to her academic career and independence, Rosamund triumphs over her professional identity crisis by fighting for a room or place within the male-dominated academic world by finishing her dissertation on schedule and getting a position offer from one of the most prestigious universities. Rosamund chooses to embrace the "flight from womanhood" (Horney 1926), but her flight from femininity is prevented by her pregnancy, which begins to transform her split identity into a kind of salvation. Then, she overcomes her final identity crisis of maternity by continuing to her career and balancing her motherhood and career successfully. Finally, conflating the features of bildungsroman with postmodern feminist fiction, Drabble challenges to the traditional conception of female identity, self, and body as the other, non-subject and secondary with her strong feminist protagonist Rosamund who achieves salvation and her true self-identity through gradually growing into maturity, self-exploration, self-realization, and self-awareness at the end of her selfdiscovery journey. Through Rosamund, the novel portrays that academic women still face societal expectations to choose either their career or traditional gender roles, or they are expected to carry extra burden or millstones on their shoulders with multiple roles and identities. Drabble depicts that there should always be an alternative hope for women to fulfill themselves without selfsacrificing. Thereby, the feminist ideology conveys that reproduction cannot be a millstone to women's career and women can fulfill themselves in career, motherhood, womanhood, and femininity together or separately without the need to make any choices as long as "one-sided domain of power ends in all spheres of life" (Buran, 2020).

\section{WORKS CITED}

Ahmed, Sara (1998). Differences that Matter: Feminist Theory and Postmodernism. United Kingdom: Cambridge University Press.

Allan, Tuzyline Jita (1995). Womanist and Feminist Aesthetics: A Comparative Review. Athens: Ohio University.

Arreger, Constance E. (1996). Graduate Women at Work: A Study by a Working Party of the British Federation of University Women. London: Oriel P. 
Bailey, Gordon and Gayle, Noga (2008). Ideology: Structuring Identities in Contemporary Life. Toronto: Higher Education University of Toronto.

Beards, Virginia K. (1973). “Margaret Drabble: Novels of a Cautious Feminist.” Critique Vol. 15, No. 1. (pp. 35-47).

Beebe, Maurice (1964). Ivory Towers and Sacred Founts: The Artist as Hero in Fiction from Goethe to Joyce. New York University.

Blackstone, Tessa (1974). "Women Academics in Britain." Women in Higher Education: Papers from a Conference Held in London on 29 June 1973, David Warren Piper (ed). London: Institute of Education. (pp. 43-67).

Bromberg, Pamela S. (1986). “The Development of Narrative Techniques in Margaret Drabble's Novels." The Journal of Narrative Technique, Vol. 16, No. 3. (pp. 179-191).

Buran, Sumeyra. (2020, August 18). "Violence against Women in Science: The Future of Gender and Science in Gwyneth Jones's Life." Critique: Studies in Contemporary Ficiton, Retrieved from https://doi.org/10.1080/00111619.2020.1803195.

Butler, Judith (1990). Gender Trouble: Feminism and the Subversion of Identity. London: Routledge.

- . Your Behavior Creates Your Gender, Short Video on BigThink.com. 2010. 09 December 2015. < http://bigthink.com/videos/your-behavior-creates-your-gender>.

Chafetz, Janet Saltzman and Hagan, Jacqueline (2003). "The Gender Division of Labor and Family Change in Industrial Societies, A Theoretical Accounting." Family: Critical Concepts in Sociology, David Cheal (ed). London: Routledge.

Cunningham, Gail (1982). "Women and Children First: The Novels of Margaret Drabble." Twentieth Century Women Novelists, Thomas F. Staley (ed). Totowa, N.J.: Barnes \& Noble Books. (pp. 130-152).

De Beauvoir, Simone (1952). The Second Sex. H.M. Parsley (ed). New York: Alfred A. Knopt, Inc. Drabble, Margaret (1973). “A Woman Writer.” Books, Vol. 11, (September). (pp.4-6).

- (1972). "How Not To Be Afraid of Virginia Woolf.” Ms. Magazine, November. (pp. 68- 70).

- (1968). The Millstone. USA: Harvest, Harcourt Brace \& Company.

Ebert, Teresa L. (1991). “The 'Difference' of Postmodern Feminism.” College English, Vol. 53, No. 8. (pp. 886-904).

Felski, Rita (1989). Beyond Feminist Aesthetics. Harward University Press.

Firchow, Peter E. (1976). "Rosamund`s Complaint: Margaret Drabble`s The Millstone (1966).” Old Lines, New Forces: Essays on the Contemporary British Novel, 1960-1970, Robert K. Morris (ed.). Rutherford: Fairleigh Dickinson UP.

Friedan, Betty (2001). The Feminine Mystique. United Kingdom: W. W. Norton.

Giroux, Henry A. (1991). Postmodernism, Feminism, and Cultural Politics: Redrawing Educational Boundaries. United States: State University of New York Press.

Gubar, Susan, and Gilbert, Sandra M. (2000). The madwoman in the attic: the woman writer and the nineteenth-century literary imagination. United Kingdom: Yale University Press. 
Guenther, Katja M. (2010). “Feminist Organizing Under Socialism and Capitalism A World Reopened." Making Their Place: Feminism After Socialism in Eastern Germany. California: Stanford University.

Hardin, Nancy S. (1973a). "An Interview with Margaret Drabble.” Contemporary Literature, Vol. 14, No. 3. (pp. 273-295).

- (1973b). “Drabble`s The Millstone: A Fable of Our Times.” Critique, Vol. 15. (pp. 22-34).

Heilbrun, Carolyn G. (1993). Reinventing Womanhood. United States: Norton.

Hekman, Susan J. (2013). Gender and Knowledge: Elements of a Postmodern Feminism. Germany: Wiley.

Heward, Christine (1996). "Women and Careers in Higher Education: What is the Problem?" Breaking Boundaries: Women in Higher Education, Louise Morley and Val Walsh (ed). London: Taylor \& Francis.

Horney, K. (1926) "The flight from womanhood: the masculinity complex in women as viewed by men and by women." Internat J. Psycho-Anal, Vol. 7. (pp. 324-339).

Hutcheon, Linda (1998). A Poetics of Postmodernism: History, Theory, Fiction. New York: Routledge.

Josselson, Ruthellen (1998). Revising Herself: The Story of Women's Identity from College to Midlife. United States: Oxford University Press.

Keller, Evelyn Fox (1985). Reflections on Gender and Science. New Haven: Yale University Press.

Kottiswari, W. S. (2008). Postmodern feminist writers. India: Sarup \& Sons.

Kümbet, Pelin (2018). "Psyche Unveiled: A Palpable Example of Female Gothic Genre, Ann Radcliffe's the Mysteries of Udolpho." KOSBED, Vol. 36. (pp. 77-94).

Labovitz, Esther Kleinbord (1986). The Myth of the Heroine: The Female Bildungsroman in the Twentieth Century. New York: Peter Lang.

Laing, Ronald David (1978). The Divided Self. London: Penguin.

Lee, Alison (1990). Realism and Power: Postmodern British Fiction. New York: Routledge.

Libby, Marion Vlastos (1975). "Fate and Feminism in the Novels of Margaret Drabble." Contemporary Literature, Vol. 16, No. 2. (pp. 175-192).

Martins Lamb, Vanessa (2011). The 1950's and the 1960's American Woman: the Transition from the "Housewife" to the Feminist. Diss. Toulon U, Toulon: Dépôt universitaire de Mémoires après soutenance. < http://dumas.ccsd.cnrs.fr/dumas-00680821>.

McGuire, Meredith B. (2008) Religion: The Social Context. Fifth Edition. United States: Waveland Press.

Myer, Valerie Grosvenor, Drabble: A Reader`s Guide, London: Vision, 1991.

Nancy Poland (1975). “Margaret Drabble: 'There Must Be a Lot of People Like Me." Midwest Quarterly, Vol. 16, No. 3. (pp. 255-67).

Nicholson, Linda J. (ed) (2013). Feminism/Postmodernism. United States, Taylor \& Francis.

Ollerenshaw, Kathleen (1961). Education of Girls. London: Faber and Faber.

Özer Taniyan, Reyhan (2012). "A Heterotopian Novel: Atwood's The Handmaid's Tale." Çankaya University Journal of Humanities and Social Sciences, Vol. 9, No. 2. (pp. 251-259). 
Parpart, Jane L. and Marchand, Marianne H. (2003). Feminism/ Postmodernism/ Development. N.p., Taylor \& Francis.

Rayson, Ann (1978). "Motherhood in the Novels of Margaret Drabble." Frontiers: A Journal of Women Studies, Vol. 3, No. 2. (pp. 43-46).

Rose, Ellen Cronan (1980). The Novels of Margaret Drabble: Equivocal Figures. London: Macmillan.

Seiler- Franklin, Carol (1979). Boulder-pushers: Women in the Fiction of Margaret Drabble, Doris Lessing, and Iris Murdoch. Bern: Peter Lang.

Showalter, Elaine (1977). A Literary of Their Own: British Women Novelists from Bronte to Lessing. United Kingdom: Princeton University Press.

Smith, Rosi (2008). "Seeing Through the Bell Jar: Distorted Female Identity in Cold War America." Aspeers, Vol. 1. (pp. 33-55).

Soule, George (1998). Four British Women Novelists: Anita Brookner, Margaret Drabble, Iris Murdoch, Barbara Pym: an Annotated and Critical Secondary Bibliography. United Kingdom: Scarecrow Press.

Speelman, G. M. (2001). Keeping Faith: Muslim-Christian Couples and Interreligious Dialogue. Netherlands: Rijksuniverstiteit Groningen.

Spitzer, Susan (1978). "Fantasy and Femaleness in Margaret Drabble`s "The Millstone." A Forum on Fiction, Vol. 11, No. 3. (pp. 227-247).

Stratton, Jon (1990). Writing Sites: A Genealogy of the Postmodern World. Ann Arbor: U of Michigan P. Suleiman, Susan Rubin (1985). “Writing and Motherhood." The (M)other Tongue: Essays in Feminist Psychoanalytic interpretation. Shirley Nelson Garner at al (eds), Ithaca: Cornell University Press. (pp. 352-377).

Tapaswi, Suhasini (2004). Feminine Sensibility in the Novels of Margaret Drabble: An Interpretation and Evolution. Indian: Atlantic.

Taylor, Charles (1992). Sources of the Self: The Making of the Modern Identity. United Kingdom: Cambridge University Press.

Waugh, Patricia (2012). Feminine Fictions: Revisiting the Postmodern. N.p., Taylor \& Francis.

Wojcik-Andrews, Ian (1995). Margaret Drabble`s Female Bildungsromane: Theory, Genre, and Gender. New York: Peter Lang.

Yoon, Sarah, and Muck, Terry (2015). Identity Crisis: Standing Between Two Identities of Women Believers from Muslim Backgrounds in Jordan. United States: Wipf and Stock Publishers. 


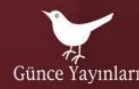

Prof. Dr. Önder Göçgün

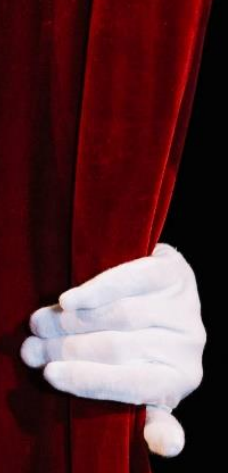

TIYYATRO DENEN HAYAT

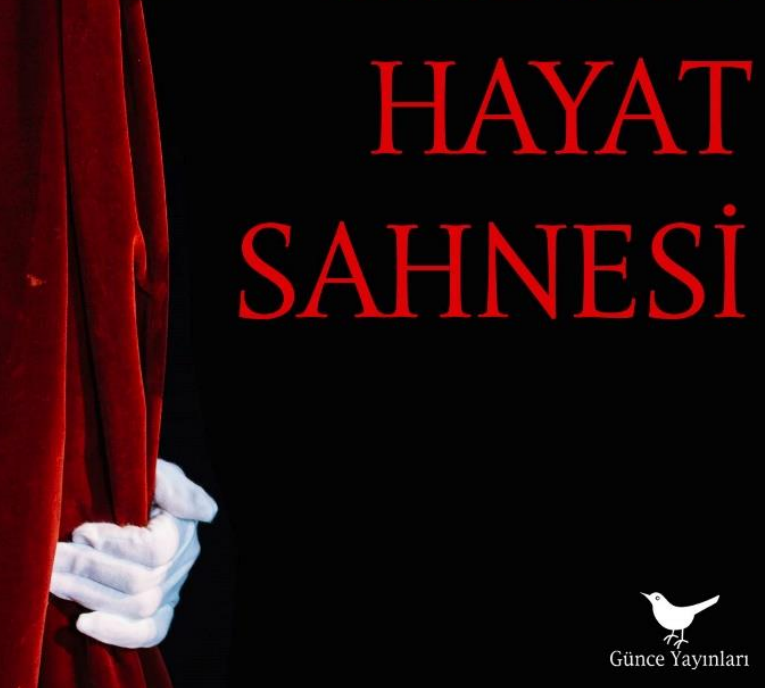

MUIIARREM DAYANC OKTAY YIVLI MACI'I BALIK MAIIMU'I BABACAN SLVIM SLERMEI
YASFMIN MUMCU BLDI் KOÇАKOĞLU NILÜLLLR ILLHAN MAKSUT YIĞITBAS SLL $\triangle M I I L \Lambda N$

\section{EDEBIYATINDA

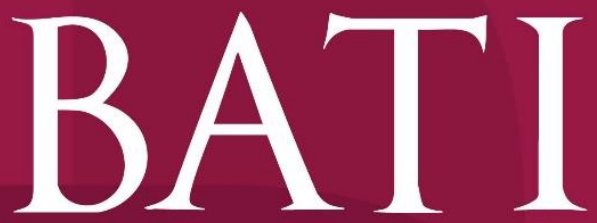 \\ EDEBIYATINDA
AKIMLAR \\ $\underset{\substack{\text { EDEBIYATINDA } \\ \text { AKIMLAR }}}{\mathrm{B} A T \mathrm{~T}}$}

editör

OKTAY YIVLI

HATICE FIRAT

YASEMIN MUMCU

OKTAY YIVLI

OĞUZHAN KARABURGU

BERNA AKYÜZ SIZGEN

NILÜFER ILHAN
ÜMMÜHAN TOPÇU

SEFA YÜCE

HANIFI ASLAN

METIN AKYÜZ

MEHMET SÜMER
YAKUP ÖZTÜRK
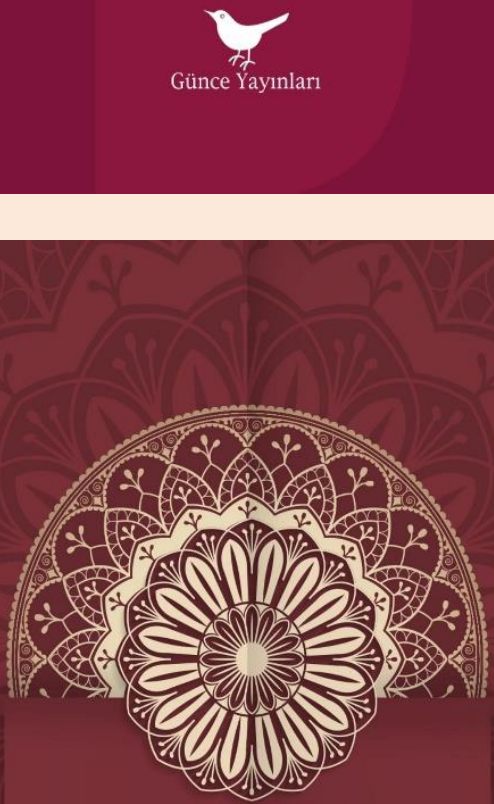

PROF. DR. ÖNDER GÖÇGÜN

$$
\begin{gathered}
\text { Türk } \\
\text { Tasavvuf } \\
\text { Siini }
\end{gathered}
$$

AÇIKLAMALI VE YORUMLU ÖRNEKLERLE 